\title{
PROLONGED HOSPITALIZATION IS A RISK FACTOR FOR DELIRIUM ONSET: ONE-DAY PREVALENCE STUDY IN SLOVENIAN INTENSIVE CARE UNITS
}

\author{
David Štubljar ${ }^{1}$, Maruša Štefin ${ }^{2}$, Marija Pia Tacar 2 , Ognjen Cerović ${ }^{3}$ and Štefan Grosek ${ }^{2,4}$ \\ ${ }^{1}$ In-Medico Department of Research and Development, Ljubljana, Slovenia; \\ ${ }^{2}$ Faculty of Medicine, University of Ljubljana, Ljubljana, Slovenia; \\ ${ }^{3}$ Clinical Department of Anesthesiology and Intensive Therapy, Centre for Intensive Therapy, \\ University Medical Centre Ljubljana, Ljubljana, Slovenia; \\ ${ }^{4}$ Department of Pediatric Surgery and Intensive Therapy, University Medical Centre Ljubljana, Ljubljana, Slovenia
}

\begin{abstract}
SUMMARY - Delirium is a clinical syndrome often underestimated in the intensive care units (ICU). The aim of this study was to determine the prevalence and factors that influence the onset of delirium. A questionnaire was sent to intensivists in Slovenian ICUs, who estimated the prevalence of delirious patients. The questionnaire consisted of demographic data, type of ICU, diagnosis, reason for admission to the ICU, type of anesthesia and surgery, clinical condition, type of supportive therapy, presence of delirium, data on discharge, transfers between departments or patient outcome on day 30. Patient consciousness was assessed by the Richmond Agitation-Sedation Scale (RASS) and the presence of delirium by the validated delirium-screening Confusion Assessment Method for the ICU (CAM-ICU). Replies received from intensivists included data on 103 patients. According to RASS $\geq-3$, the prevalence of delirium was $9.5 \%$ (7 out of 74 patients). There was no difference in the prevalence of delirium between surgical and medical ICU patients $(\mathrm{p}=0.388)$. Delirious patients had longer hospital stay $(\mathrm{p}=0.002)$ and ICU stay $(\mathrm{p}=0.032)$ compared to patients without delirium. All delirious patients survived until day 30, whereas 19 patients without delirium died $(\mathrm{p}=0.092)$. Logistic regression analysis dismissed any association of delirium with patient mortality $(\mathrm{p}=0.998)$. Age, gender, anesthesia, mechanical ventilation, and type of surgical procedure could not be evaluated as risk factors for delirium. In Slovenian ICUs, a lower proportion of delirium was observed, as reported from similar studies. Risk factors such as gender, age, mechanical ventilation, sedation, anesthesia, or department could not predict delirium. However, prolonged hospitalization of ICU patients could predict the onset of delirium, but the presence of delirium did not increase patient mortality.
\end{abstract}

Key words: Delirium; Intensive care units; Psychomotor agitation - classification; Consciousness - classification; Surgery department, hospital; Slovenia

\section{Introduction}

Delirium is a type of brain damage characterized by disturbance of consciousness with reduced attention, abnormal thinking (altered memory, orientation and language) and sensory disturbances (hallucina-

Correspondence to: David Štubljar, B.Sc., Department of Research and Development, In-Medico, Mestni trg 11, 8330 Metlika, Slovenia

E-mail: d.stubljar@gmail.com

Received March 7, 2018, accepted October 22, 2018 tions and illusions $)^{1}$, which develops over a period of few hours to several days, and its intensity changes with time ${ }^{2-4}$. In addition to the etiologic cause, the International Classification of Diseases takes into account four additional features of delirium, namely, psychomotor disturbance, sleep rhythm disorders, wakefulness and emotional disorders ${ }^{5}$. Delirium is often of transient and self-limiting nature (most patients recover within 4 weeks), but can also persist throughout hospitalization ${ }^{5}$. Particularly at high risk are elderly, patients after surgery, critically ill in intensive wards, 
and patients with advanced forms of oncologic diseases. In psychiatric intensive care units (ICUs), patients with delirium as a result of withdrawal from alcohol or sedatives and opiate abuse are often accommodated $^{6}$. Delirium is associated with many postoperative complications, e.g., prolonged hospitalization, poorer outcome of treatment, long-term cognitive decline, dementia and death ${ }^{7}$.

The prevalence of delirium in general hospital population is $10 \%-24 \%$. In surgical and medical ICUs, it varies between $20 \%$ and $80 \%$, depending on the severity and type of illness ${ }^{3,4,6}$. In patients from surgical departments, the prevalence is around $40 \%$ and is dependent on the type of operation and other associated risk factors, being highest (50\%-67\%) in patients having undergone surgery on the heart ${ }^{4}$. The frequency of delirium increases with age ${ }^{8}$. According to Wang et al. ${ }^{9}$, the incidence of postoperative delirium in elderly people ( $>65$ years) is between $15 \%$ and $53 \%$, and $80 \%$ in those hospitalized in ICUs.

Lipowski ${ }^{10}$ divided delirium into three subtypes: I hypoactive - the patient is calm, restrained, and does not respond to stimuli; II hyperactive - the patient is agitated, shows signs of aggression, may experience hallucinations and illusions; and III mixed - the patient passes from hypoactive to hyperactive and back. The most common is mixed type (46\%), followed by hyperactive delirium (30\%) and hypoactive type (25\%). The latter is often most difficult to determine ${ }^{11}$ because it can have symptoms similar to depression. Whitlock et al. ${ }^{5}$ found hypoactive delirium to be the most common form, recorded in about $50 \%$ of postoperative patients. Mixed and hyperactive types occurred in $25 \%$ of patients.

Precipitating risk factors include medicines, especially those with anticholinergic effects, withdrawal from alcohol, barbiturates or sedatives, various metabolic causes (hypoxia and respiratory failure, hypoglycemia, liver or renal insufficiency), endocrine disorders (hypo- or hyperfunction of thyroid or adrenal gland), disturbance in the balance of fluids and electrolytes, infection (sepsis, inflammation of the central nervous system, urinary tract infections), head trauma, epilepsy, neoplastic disease, cerebrovascular disease, and cardiovascular disease ${ }^{2,3,6,7,12}$. Patients from surgical departments have additional precipitating factors, i.e. intraoperative factors such as hip fractures, cardiovascular surgery, duration of surgery, shock/hypotension, ar- rhythmia, use of benzodiazepines and propofol, decreased endocardial fraction, and duration of anesthesia; and postoperative factors such as low hematocrit, cardiogenic shock, hypoxemia, prolonged intubation, sedation and pain $^{13}$.

There are several diagnostic algorithms for assessing delirium. The latest clinical recommendations for pain, agitation and delirium from 2013 by Barr et al. ${ }^{14}$ suggest regular monitoring of delirium in adult ICU with two diagnostic algorithms (validated deliriumscreening tests) Confusion Assessment Method for the ICU (CAM-ICU) or Intensive Care Delirium Screening Checklist (ICDSC) ${ }^{15}$. As recommended by The National Institute for Health and Clinical Excellence (NICE), prevention of delirium requires early recognition and adequate supervision of risk factors ${ }^{7}$. Delirium in critically ill ICU patients represents a major public health problem. It can be concluded that delirious ICU patients have a strongly increased risk of adverse outcome (prolonged duration of hospitalization, increased mortality and reduction in cognitive abilities) $)^{2,3}$.

The objective of this study was to evaluate the prevalence of delirium in Slovenian ICUs and determine the factors that influence the onset of delirium in ICU patients. A specific objective was to check if surgical ICU patients have a higher prevalence compared to medical ICU patients.

\section{Patients and Methods}

The study was designed as one-day prevalence survey of delirium in Slovenian ICUs. Patient data were collected by physicians, intensivists employed in ICU using a questionnaire. The study was approved by the National Medical Ethics Commission of the Republic of Slovenia.

\section{Patient selection and data collection}

The survey included Slovenian surgical and medical ICUs with adult patients only. Pediatric ICUs were not included because, in our experience, the proportion of delirium is extremely small in this patient population. One representative physician/intensivist from each ICU was responsible for questionnaire enrolment. The intensivists were expected to complete the questionnaire on the presence or absence of delirium 
for all patients hospitalized in their ICU who met the entry criteria on the day the survey was held.

\section{Inclusion and exclusion criteria}

The study included all patients hospitalized in adult medical or surgical ICU on the day of the survey. Patients were excluded if they were assessed for primary neurological diagnosis by Glasgow Coma Scale less than 14 at admission to the ICU or before the survey began. Additional exclusion criteria were blindness, deafness, not understanding the Slovene language, dying patients with death expected in less than 24 hours, and total time of hospitalization in the ICU less than 24 hours.

\section{Questionnaire and data studied}

For patients that met the inclusion criteria on the day of the study, the following information was collected: demographic data (gender, age), type of ICU (surgical, medical), diagnosis and reasons for admission to the ICU, type of anesthesia (conduction or general), and type of surgery (emergency or elective). This was followed by questions of whether the patient at the time of hospital admission suffered from sepsis, had acute lung injury (ALI) or acute respiratory distress syndrome (ARDS), what type of supportive therapy he/she received (dialysis, invasive mechanical ventilation, antibiotics, vasopressor agents, sedatives, analgesics), and what invasive procedures for monitoring the patient (central venous catheter, urinary catheter, arterial catheter) were needed. The central part of the questionnaire was designed to assess the state of patient consciousness and presence of delirium. To assess the state of consciousness, we used the 10-step Richmond Agitation-Sedation Scale (RASS), which measures patient agitation/sedation from -5 (unresponsive, no answer or physical stimulus) to +4 (fighting, excessive fighting, violent, threatening staff $)^{3,16}$. The presence of delirium was examined using the validated delirium-screening algorithm Confusion Assessment Method for the ICU (CAM-ICU) ${ }^{16}$.

\section{Detailed description of delirium detection}

By using CAM-ICU, delirium was diagnosed in two steps. In the first step, the state of alertness was assessed with $\mathrm{RASS}^{3}$. A patient estimated -4 or -5 by RASS is in deep sedation, so delirium cannot be as- sessed. In all other patients with values ranging from -3 to +4 it is necessary to assess the state of delirium. In the second step, CAM-ICU assessed four delirium characteristics, as follows: (i) acute change or changing state of consciousness; (ii) negligence; (iii) altered consciousness; and (iv) confusion ${ }^{3,16}$. The patient had delirium if he/she met the first two conditions, in addition even third and fourth ones ${ }^{3,16}$. The test yields assessment of delirium at the time of observation, so due to fluctuation of delirium, it is recommended to evaluate its presence several times a day. CAM-ICU is suitable for assessment of intubated patients. The test is highly sensitive (91\%-100\%) and specific (89\%-100\%) for delirium ${ }^{3,17}$.

Changes were considered acute if the patient showed signs of altered mental status or the patient's mental state changed in the last 24 hours $^{3,16}$. Altered state of consciousness was assessed by RASS. If the value was greater or less than 0 (greater than -4 , which is a prerequisite for implementing CAM-ICU), the patient was delirious and the test was concluded. If the RASS score was 0 , we continued the test and checked whether the patient was confused. In addition to these issues, if the patient made two or more errors when answering and fulfilling the commands, he/she was delirious. Less than two errors did not indicate deliri$u^{3,16}$. In our study, the types of delirium (hypoactive, hyperactive and mixed) were clinically evaluated.

\section{Statistical analysis}

Statistical analysis was performed using SPSS 21 software (IBM, New York, USA). The clinical data collected were presented as individual variables that were included in statistical analysis. For comparison of normally distributed quantitative data we performed T-test with dependent variable; in this study it was the presence of delirium. For abnormally distributed variables, non-parametric Kruskal-Wallis test was used. Qualitative data were evaluated using Pearson's $\chi^{2}$-test, where we determined statistical difference between independent variables and delirium as the dependent variable to assess statistical significance between the variables. Statistical differences were considered to be significant at $\mathrm{p}<0.05$. Furthermore, statistical correlation of each variable with Pearson's $\chi^{2}$ correlation analysis was examined. For variables that were statistically significantly correlated with the presence of delirium, logistic regression was performed to calculate the pre- 
dictive value with odds ratio $(\mathrm{OR})$ and associated $\mathrm{p}^{-}$ values.

In all 103 patients, the condition was estimated on day 30 of observation. Outcome was defined as good (improvement) or poor (deterioration or death). Prognostic value for the presence of delirium was evaluated on day 30 of hospital stay with the Kaplan-Meier survival curve.

\section{Table 1. Main characteristics of 103 study patients}

\begin{tabular}{|l|l|}
\hline Characteristics & Patients (N=103) \\
\hline Age (years) & $66.9 \pm 14.19$ \\
\hline Gender & $62(60.2 \%)$ \\
Male & $41(39.8 \%)$ \\
\hline Female & $60(58.3 \%)$ \\
Mensive care unit & $43(41.7 \%)$ \\
Surgical & $24(23.3 \%)$ \\
\hline Diagnosis & $21(20.4 \%)$ \\
Sepsis & $27(26.2 \%)$ \\
Cardiovascular diseases & $5(4.9 \%)$ \\
Respiratory diseases & $13(12.6 \%)$ \\
Neurologic diseases & $-1.4 \pm 2.09$ \\
Other & $7(6.8 \%)$ \\
\hline RASS & $22.1 \pm 16.68$ \\
\hline Delirium & $34(33.0 \%)$ \\
\hline Hospital stay (days) (n=57) & $63(61.2 \%)$ \\
\hline Outcome & \\
Discharged from hospital & On day 30 still hospitalized \\
or dead & \\
\hline
\end{tabular}

RASS $=$ Richmond Agitation-Sedation Scale

\section{Results}

Our one-day prevalence study included $103 \mathrm{pa-}$ tients from Slovenia hospitalized at ICU for various disease states (sepsis, cardiovascular, respiratory, neurological disease, etc.) and completely meeting inclusion criteria for final analysis. Overall, 29 Slovenian adult ICUs were invited to take part in the survey. Completed questionnaires were received from 22 (75.9\%) ICUs. Patients were divided into two groups, i.e. a group of cases where delirium was confirmed and a group of controls where delirium was not proven. Table 1 shows basic characteristics of patients who were eligible for the survey and then included in the study. Seventy-four patients had RASS score equal or higher than -3 and fulfilled the criteria for the potential onset of delirium. The presence of delirium was recorded in seven (9.5\%) out of 74 patients. Three patients that suffered from delirium were transferred to ICU from home, two from medical department and two after surgery. No statistical difference in delirium $(p=0.388)$ was observed between surgical and medical ICU patients.

Comparison of patients without delirium $(n=67)$ and those having developed delirium $(n=7)$ revealed statistically significant differences between the groups according to age and RASS score $(\mathrm{p}=0.922$ and $\mathrm{p}=0.076$, respectively). Although total hospitalization could only be determined in 57 patients, there was a statistically significant difference in the duration of hospital stay $(\mathrm{p}=0.002)$. Furthermore, when observing these 57 patients, we found that they spent half of all hospital days in ICU. Five patients with delirium stayed in ICU for 25 days on average, whereas $52 \mathrm{pa}-$ tients without delirium stayed in ICU for 11 days on average, yielding a statistically significant difference

Table 2. Comparison of quantitative data (t-test or Kruskal-Wallis test) and mortality (Pearson's $\chi^{2}$-test) in patients without and with delirium

\begin{tabular}{|l|l|l|l|}
\hline & \multicolumn{2}{|c|}{ Patients } & \multirow{2}{*}{-value } \\
\cline { 2 - 4 } & Without delirium $(\mathrm{n}=67)$ & With delirium $(\mathrm{n}=7)$ & \\
\hline Age (years) & $67.3 \pm 14.81$ & $66.7 \pm 9.60$ & 0.922 \\
RASS & $-0.4 \pm 1.10$ & $0.4 \pm 2.22$ & 0.076 \\
Hospital stay (days) $(\mathrm{n}=57)$ & $20.0 \pm 11.85$ & $44.0 \pm 33.65$ & 0.002 \\
ICU stay (days) $(\mathrm{n}=57)$ & $11.6 \pm 9.24$ & $25.8 \pm 31.69$ & 0.032 \\
Death & $19(28.4 \%)$ & 0 & 0.092 \\
\hline
\end{tabular}

RASS = Richmond Agitation-Sedation Scale; ICU = intensive care unit 
Table 3. Calculated predictive values with odds ratio (OR) and 95\% confidence interval (95\% CI) predicting the onset of delirium in ICU patients

\begin{tabular}{|l|l|l|}
\hline & $\begin{array}{l}\text { Predictive values } \\
\text { for delirium }\end{array}$ & \multirow{2}{*}{ p-value } \\
\cline { 2 - 3 } & OR (95\% CI $)$ & \\
\hline Age & $1.00(0.95-1.05)$ & 0.920 \\
Gender & $5.66(0.65-49.54)$ & 0.117 \\
RASS & $1.83(0.94-3.55)$ & 0.076 \\
Stay at ICU & $1.00(0.97-1.02)$ & 0.816 \\
Hospitalization & $1.07(1.00-1.15)$ & 0.050 \\
Type of department & $0.48(0.09-2.63)$ & 0.396 \\
Intervention & $1.07(0.22-5.17)$ & 0.931 \\
Type of surgery & $0.95(0.08-11.87)$ & 0.967 \\
Anesthesia* & $/$ & 0.999 \\
Sepsis & $2.03(0.42-9.77)$ & 0.380 \\
ALI & $1.23(0.22-6.94)$ & 0.819 \\
ARDS & $0.72(0.08-6.57)$ & 0.773 \\
Sepsis+ALI+ARDS & $1.30(0.56-3.02)$ & 0.539 \\
Dialysis & $0.59(0.07-5.28)$ & 0.636 \\
Mechanical ventilation* & $/$ & 0.998 \\
Antibiotics* & $/$ & 0.999 \\
Vasopressors & $0.49(0.10-2.38)$ & 0.380 \\
Sedation* & $/$ & 0.999 \\
CVC* & $/$ & 0.999 \\
UC* & $/$ & 0.999 \\
AC* & $/$ & 0.999 \\
Diagnosis at admission & $1.05(0.57-1.91)$ & 0.882 \\
Outcome & $2.63(0.62-11.20)$ & 0.191 \\
Death* & $/$ & 0.998 \\
Admission & $1.36(0.82-2.26)$ & 0.239 \\
Sum of therapy & $/$ \\
\hline
\end{tabular}

RASS $=$ Richmond Agitation-Sedation Scale; ICU = intensive care unit; $\mathrm{ALI}=$ acute lung injury; $\mathrm{ARDS}=$ acute respiratory distress syndrome; $\mathrm{CVC}=$ central venous catheter, $\mathrm{UC}=$ urinary catheter; $\mathrm{AC}=$ arterial catheter; ${ }^{*}$ variables not statistically associated with delirium

$(\mathrm{p}=0.032)$. Delirious patients stayed in hospital and consequently in ICU more than twice as long. The mean values of these data are shown in Table 2 .

All seven delirious patients survived until day 30 of observation, whereas 19 of 74 patients without delirium eventually died (Table 2). The difference was not statistically significant $(p=0.092)$. Furthermore, binary logistic regression showed that delirium could not influence mortality ( $\mathrm{p}=0.998$ ).

Pearson's correlation analysis showed positive correlation between delirium and mechanical ventilation ( $\mathrm{rho}=0.248 ; \mathrm{p}=0.032$ ), duration of hospitalization (rho=0.453; $\mathrm{p}=0.002$ ), and consequently staying in ICU (rho=0.318; $\mathrm{p}=0.032$ ). Other variables were not correlated with delirium. Factors that might predict the onset of delirium in patients lying in ICU are shown in Table 3. Tested parameters could not predict delirium for ICU patients. However, longer hospitalization of patient showed probability with odds ratio $\mathrm{OR}=1.07$ (95\% confidence interval (CI) 1.00-1.15) for the presence of delirium.

Table 4 shows differences according to different diagnoses at admission. It reveals a statistically significant differences for ICU stay ( $\mathrm{p}=0.016$ ), but diagnoses had no effect on the value of RASS and total duration of hospital stay.

\section{Discussion}

The aims of this one-day prevalence study in Slovenian ICUs were to determine the presence of delirium in ICU patients and to evaluate the proportion of these patients from medical or surgical departments during treatment in ICU. According to international data, the prevalence of delirium in ICU patients is high and depends on several triggering factors. In Slovenian area, such research has not been carried out yet, so we wanted to find out how big is the problem of delirium in Slovenian adult ICUs. The information necessary for the investigation was obtained by a questionnaire. We wanted to check the following hypotheses, namely, we expected lower delirium prevalence in Slovenian ICUs compared to foreign studies and a higher prevalence in surgical compared to medical ICU patients.

We confirmed delirium in only seven $(9.5 \%)$ of 74 patients whose RASS score was equal or higher than -3. Patients were referred to medical and surgical ICUs. Sixty-one (59.2\%) of 103 patients, and then 47 (63.5\%) of 74 (RASS $\geq-3$ ) patients were mechanically ventilated during the study, which was considered as the high intensity treatment in ICU. In comparable foreign studies, the proportion of detected delirium was much higher, while the intensity of treatment was often lower. Salluh et al. ${ }^{16}$ conducted a similar one-day 
Table 4. Differences in patient characteristics according to admission diagnosis

\begin{tabular}{|l|l|l|l|l|}
\hline Diagnosis & Age (years) & RASS & ICU (days) & Hospital stay (days) \\
\hline Sepsis & $67.9 \pm 17.14$ & $-1.9 \pm 2.23$ & $25.0 \pm 25.49$ & $23.7 \pm 19.19$ \\
Cardiovascular diseases & $65.3 \pm 13.34$ & $-1.5 \pm 2.31$ & $10.8 \pm 9.43$ & $14.5 \pm 9.47$ \\
Respiratory diseases & $66.8 \pm 15.56$ & $-1.3 \pm 1.85$ & $24.5 \pm 20.30$ & $27.1 \pm 23.48$ \\
Neurologic diseases & $64.0 \pm 13.32$ & $-1.6 \pm 2.40$ & $39.0 \pm 37.72$ & $18.0 \pm 0.0$ \\
Others & $69.2 \pm 9.22$ & $-0.1 \pm 0.45$ & $11.1 \pm 9.19$ & $22.7 \pm 12.00$ \\
p-value & 0.928 & 0.133 & 0.016 & 0.376 \\
\hline
\end{tabular}

RASS = Richmond Agitation-Sedation Scale; ICU = intensive care unit

prevalence research in ICU departments, which included 479 patients, and finally delirium could be evaluated in 232 patients. The proportion of delirious patients was $32 \%$, which is almost five-fold greater proportion recorded in our study. We found this percent extremely high for one-day prevalence study because in our previous unpublished one-day prevalence pilot study from 2014, there were only four (4.6\%) delirious patients out of 87 patients included. Thomason et al. ${ }^{8}$ involved a larger number of ICU departments and included 261 patients with internal diseases requiring no mechanical ventilation. They confirmed $48 \%$ of patients with delirium. Moreover, Ely et al. ${ }^{18}$ showed even higher proportions of patients with delirium (60\%-80\%) in medical ICU.

In our study, only 7 cases of delirium could be attributed to the fact that only $60 \%$ of examined patients were mechanically ventilated during the research, and they probably also needed sedation and analgesia, which could eventually mislead to accurate identification of delirium. However, when we compared the group of mechanically ventilated patients with and without delirium, we did not find any statistically significant differences between the groups, which excluded mechanical ventilation as a risk factor for delirium. Similar findings have been reported by Ely et al. ${ }^{18}$. The type of anesthesia could not be the cause of low percentage of delirium either because we did not find statistically significant difference between patients with and without delirium. This is consistent with the survey by Mason et al. ${ }^{19}$, who performed a meta-analysis of 14 articles about anesthesia and occurrence of delirium in the 1985-2007 period. Furthermore, our results suggested that catheterization, mechanical ventilation, and intubation did not represent risk factors for delirium, which is in conflict with the results of Leite et $a l .^{20}$, who proved otherwise. The reasons for lower proportion of delirium could not be identified. Had we prolonged the current study to a week, we would have certainly detected a higher percentage of delirious patients. Comparison with foreign studies indicated that our patients could have been even more prone to delirium (older age, male gender, high proportion of mechanical ventilation, etc.), but it was evident that they were not. Of course, there are much more risk factors for delirium. However, we must not ignore the fact that there are genetic factors that influence a higher or lower prevalence of delirium. Thus, Girard et al. ${ }^{3}$ found a link between apolipoprotein E genotype (APOE) and duration of delirium in critically ill patients. In those with ApoE4 polymorphism, which represents a risk factor for Alzheimer's disease, the duration of delirium was twice longer than in those without this type of polymorphism.

The average age of our delirious patients was comparable to the age of patients without delirium. This is mentioned because average age of delirious patients in many surveys was much higher. For instance, Thomason et al. ${ }^{8}$ report that patients with delirium were on average 7 years older than patients without delirium. Older patients are often burdened by a number of chronic diseases (hypertension) and impaired cognitive functions, which may be predisposing factors for the onset of delirium ${ }^{2,3,6,7,12,14,21,22}$. Patients in our study had average age of 66 years, which is 10 years more than in the survey by Thomason $e t a .^{8}$, and yet the proportion of delirious patients was nine times lower.

This research demonstrated minor difference in the values of RASS, which define the state of consciousness and alertness of patients, between delirious patients and patients without delirium. Delirious patients had a higher average value of RASS than pa- 
tients without delirium. Our results are consistent with the results of Salluh et al. ${ }^{16}$. All three types of delirium were identified; three patients had hypoactive form, two had mixed form, and two had hyperactive form of delirium. It is known that mixed type is most common (46\%), followed by hyperactive delirium (30\%) and hypoactive delirium $(25 \%)^{4,11}$. Patients with hypoactive delirium should have lower RASS values than patients with hyperactive delirium ${ }^{16}$. Our results did not confirm these findings because we detected significantly higher RASS values for mixed and hyperactive types. In our study, patients with hypoactive type had negative RASS values.

Other studies showed a higher prevalence of delirium in male patients ${ }^{3,4,6,7,12}$. However, clear explanations for these differences were not found. Unlike other studies, we did not find statistically significant differences according to gender. Moreover, sedatives and analgesics, which are used daily in ICU, especially for mechanically ventilated patients to relieve pain and anxiety, might also have negative effects. Studies showed that morphine medication was a key prognostic factor for delirium ${ }^{3}$. The use of sedatives did not show significant correlation with delirium in our patient population.

We assume that after 20 days of hospitalization in ICU, improvement of primary health condition occurred. Although some patients developed delirium, they were transferred to the ward. Patients with delirium were hospitalized twice as long, and also stayed twice as long in ICU. Our results are consistent with the results of other studies, where patients with delirium had prolonged hospital stay ${ }^{2-4,16}$. The reason could be that patients with delirium were already transferred to other department.

Disease outcome (death, staying in hospital, or discharge) was indicated, but the prognostic value showed no difference. All seven delirious patients survived and remained hospitalized, whereas 19 patients without delirium died. Therefore, longer hospitalization predicted the presence of delirium in ICU patients, but delirium could not predict 30-day mortality or disease outcome. In the past, delirium was associated with many postoperative complications, e.g., prolonged hospitalization, poorer outcome of treatment, longterm cognitive decline, dementia and death ${ }^{7}$, which we partially confirmed.

Of the seven confirmed delirious patients, five came from medical department and two from surgical department. Department did not play important role in the presence of delirium ( $\mathrm{p}=0.388)$. Among surgical patients, the highest proportions of delirium have been recorded for patients after heart and hip surgery. Maldonado et al. ${ }^{4}$ found the prevalence of patients with delirium in medical ICU to be $60 \%-80 \%$ and on surgical wards $10 \%-60 \%$, depending on the type of surgery. The highest proportion of delirious patients in surgical ICUs was in patients having undergone hip surgery $(35 \%-65 \%)^{13}$, and in cardiac departments, especially after heart surgery with cardiomyotomy $(50 \%-67 \%)^{4}$. Watne et al. ${ }^{23}$ report on a similar high percent of delirium in elderly surgical patients; delirium was detected in $51 \%$ of all hip surgeries. Olofsson et al. ${ }^{24}$ also studied the proportion of delirium in elderly patients after hip fracture surgery and showed that delirium occurred in $62 \%$ of patients. Schroder et al..$^{25}$ studied delirium in patients undergoing cardiac surgery and found the proportion of patients with delirium to be $67 \%$. It is important to highlight that the authors assessed up to three times higher proportion of delirium in the emergency hip surgeries compared to elective interventions on the hip ${ }^{12,15}$. Our results showed significantly lower proportions of delirium in postoperative patients compared to these studies. We found no difference between elective and emergency interventions either. From the collected and analyzed data, we cannot explain why our prevalence of delirium was significantly lower than in other studies. One explanation could be that we did not recognize hypoactive forms of delirium, since Whitlock et al. ${ }^{5}$ found that postoperative patients most commonly showed hypoactive form (50\%).

Our study had some limitations. It was designed as a one-day prevalence study, making it impossible to include a larger number of patients. For this reason, we need to evaluate our results with caution. On the other hand, we managed to include patients from more than $70 \%$ of Slovenian ICUs. Although the study was short, data acquisition was excellent. A multicenter prospective study including more patients over time could give better answers to the questions. Certainly, a one-day prevalence survey is a good starting point and good design for further research.

\section{Conclusions}

We can conclude that in Slovenian ICUs, a lower proportion of delirium was observed compared to sim- 
ilar foreign research. Some risk factors that were mentioned in foreign studies were not statistically significant in our study, such as gender, age, type of intensive unit, the proportion of mechanical ventilation, sedation, type of anesthesia, etc. We believe that a longer prospective study could give detailed answers to the questions. To emphasize, we did not find significant difference between surgical and medical ICU patients, so we can conclude that it does not matter where the patients are staying, only long hospital stay could predict the onset of delirium.

\section{Acknowledgments}

The authors express gratitude to all Slovenian intensivists who participated in the study and helped the study to be completed successfully.

\section{References}

1. Morandi A, Pandharipande P, Trabucchi M, Rozzini R, Mistraletti G, Trompeo AC, et al. Understanding international differences in terminology for delirium and other types of acute brain dysfunction in critically ill patients. Intensive Care Med. 2008;34(10):1907-15, https://doi.org/10.1007/s00134008-1177-6

2. Connor D, English W. Delirium in critical care. Update Anaesthesia. 2012;28:67-73, doi: 10.1186/cc6149

3. Girard TD, Pandharipande PP, Ely EW. Delirium in the intensive care unit. Crit Care. 2008;12(Suppl 3):S3, doi: 10.1186/ cc6149

4. Maldonado JR. Delirium in the acute care setting: characteristics, diagnosis and treatment. Crit Care Clin. 2008;24(4): 657-722, https://doi.org/10.1016/j.ccc.2008.05.008

5. Whitlock EL, Vannucci A, Avidan MS. Postoperative delirium. Minerva Anestesiol. 2011;77(4):448-56.

6. Korošec Jagodič H, Jagodič K, Pregelj P. Management of delirium. Zdrav Vestn. 2009;78:473-80.

7. Young J, Murthy L, Westby M, Akunne A, O'Mahony R, Guideline Development Group. Diagnosis, prevention, and management of delirium: summary of NICE guidance. BMJ. 2010;341:c3704, doi: https://doi.org/10.1136/bmj.c3704

8. Thomason JW, Shintani A, Peterson JF, Pun BT, Jackson JC, Ely EW. Intensive care unit is an independent predictor of longer hospital stay: a prospective analysis of 261 non-ventilated patients. Crit Care. 2005;9(4):R375-81, doi: 10.1186/cc3729

9. Wang W, Li HL, Wang DX; Zhu X, Li SL, Yao GQ et al. Haloperidol prophylaxis decreases delirium incidence in elderly patients after noncardiac surgery: a randomized controlled trial. Crit Care Med. 2012;40(3):731-9, doi: 10.1097/ CCM.0b013e3182376e4f
10. Lipowski Z. Transient cognitive disorders (delirium, acute confusional states) in the elderly. Am J Psychiatry. 1983; 140:1426-36, https://doi.org/10.1176/ajp.140.11.1426

11. Yang FM, Marcantonio ER, Inouye SK, Kiely DK, Rudolph $\mathrm{JL}$, Fearing MA, et al. Phenomenological subtypes of delirium in older persons: patterns, prevalence, and prognosis. Psychosomatics. 2009;50(3):248-54, doi: 10.1176/appi.psy.50.3.248

12. Inouye SK, Bogardus ST Jr, Charpentier PA, Leo-Summers L, Acampora D, Holford TR, et al. A multicomponent intervention to prevent delirium in hospitalized older patients. N Engl J Med. 1999;340(9):669-76, doi: 10.1056/NEJM199903043400901

13. Rudolph JL, Marcantonio ER. Review articles: postoperative delirium: acute change with long-term implications. Anesth Analg. 2011;112(5):1202-11, doi: 10.1213/ANE.0b013e3182147f6d

14. Barr J, Fraser GL, Puntillo K, Ely EW, Gélinas C, Dasta JF, et al. Clinical practice guidelines for the management of pain, agitation, and delirium in adult patients in the intensive care unit: executive summary. Am J Health Syst Pharm. 2013; 70(1):53-8, doi: 10.1097/CCM.0b013e3182783b72

15. Barr J, Fraser GL, Puntillo K, Ely EW, Gélinas C, Dasta JF, et al. Clinical practice guidelines for the management of pain, agitation, and delirium in adult patients in the intensive care unit. Crit Care Med. 2013;41(1):263-306, doi: 10.1097/ CCM.0b013e3182783b72

16. Salluh JI, Soares M, Teles JM, Ceraso D, Raimondi N, Nava VS, et al. Delirium Epidemiology in Critical Care (DECCA): an international study. Crit Care. 2010;14(6):P210, doi: $10.1186 /$ cc9333

17. Brummel NE, Vasilevskis EE, Han JH, Boehm L, Pun BT, Ely EW. Implementing delirium screening in the ICU: secrets to success. Crit Care Med. 2013;41(9):2196-208, doi: 10.1097/ CCM.0b013e31829a6f1e

18. Ely W, Shintani A, Truman B, Speroff T, Gordon S, Harrell F, et al. Delirium as a predictor of mortality in mechanically ventilated patients in the intensive care unit. JAMA. 2004; 291:1753-62, doi:10.1001/jama.291.14.1753

19. Mason SE, Noel-Storr A, Ritchie CW. The impact of general and regional anesthesia on the incidence of post-operative delirium: a systematic review with meta-analysis. J Alzheimers Dis. 2010;22(Suppl 3):67-79, doi: 10.3233/JAD-2010-101086

20. Leite MA, Osaku EF, Costa CR, Cândia MF, Toccolini B, Covatti C, et al. Delirium during weaning from mechanical ventilation. Crit Care Res Pract. 2014;2014:546349, doi: 10.1155/2014/546349

21. Devlin JW, Mallow-Corbett S, Riker RR. Adverse drug events associated with the use of analgesics, sedatives, and antipsychotics in the intensive care unit. Crit Care Med. 2010;38 (6 Suppl):S231-43, doi: 10.1097/CCM.0b013e3181de125a

22. Gusmao-Flores D, Salluh JI, Dal-Pizzol F, Ritter C, Tomasi $\mathrm{CD}$, Lima MA, et al. The validity and reliability of the Portuguese version of three tools used to diagnose delirium in criti- 
cally ill patients. Clinics (Sao Paulo). 2011;66(11):1917-22, doi: 10.1590/S1807-59322011001100011

23. Watne LO, Torbergsen AC, Conroy S, Engedal K, Frihagen F, Hjorthaug GA, et al. The effect of a pre- and postoperative orthogeriatric service cognitive function in patients with hip fracture: randomized controlled trial (Oslo Orthogeriatric Trial). BMC Med. 2014;15(12):63, doi: 10.1186/1741-7015-12-63

24. Olofsson B, Lundström M, Borssen B, Nyberg L, Gustafson Y. Delirium is associated with poor rehabilitation outcome in elderly patients treated for femoral neck fractures. Scand J Caring Sci. 2005;19(2):119-27, https://doi.org/10.1111/j.1471-6712.2005.00324.x

25. Schroder Pedersen S, Kirkegaard T, Balslev Jorgensen M, Lind Jorgensen V. Effects of a screening and treatment protocol with haloperidol on post-cardiotomy delirium: a prospective cohort study. Interact Cardiovasc Thorac Surg. 2014;18(4):438-45, doi: $10.1093 /$ icvts/ivt501

Sažetak

\section{PRODUŽENA HOSPITALIZACIJA JE RIZIČNI ČIMBENIK ZA NASTANAK DELIRIJA: JEDNODNEVNA STUDIJA UČESTALOSTI U SLOVENSKIM INTENZIVNIM JEDINICAMA}

\section{D. Štubljar, M. Štefin, M. P. Tacar, O. Cerović i Š. Grosek}

Delirij je klinički sindrom koji se često podcjenjuje u jedinicama intenzivnog liječenja (JIL). Cilj ovog istraživanja bio je utvrditi učestalost i čimbenike koji utječu na pojavu delirija. Upitnik je poslan intenzivistima u slovenskim jedinicama za intenzivno liječenje, koji su procijenili učestalost bolesnika s delirijem. Upitnik se sastojao od demografskih podataka, vrste intenzivnog liječenja, dijagnoze, razloga za prijam u JIL, vrste anestezije i operacije, kliničkog stanja, vrste potporne terapije, prisutnosti delirija, podataka o iscjedku, prijenosa između odjela ili ishoda bolesnika 30. dana. Svijest bolesnika je procijenjena pomoću Richmondove ljestvice za agitaciju-sedaciju (RASS), a prisutnost delirija pomoću validirane metode za procjenu konfuzije za primjenu u JIL (CAM-ICU). Odgovori dobiveni od intenzivista uključivali su podatke za 103 bolesnika. Prema RASS $\geq-3$, učestalost delirija bila je $9,5 \%$ (7 od 74 bolesnika). Nije bilo razlike u učestalosti delirija između kirurških i medicinskih bolesnika u intenzivnim odjelima $(p=0,388)$. Bolesnici s delirijem imali su duži boravak u bolnici $(p=0,002)$ i boravak u JIL ( $p=0,032)$ u usporedbi s bolesnicima bez delirija. Svi bolesnici s delirijem preživjeli su do 30. dana, dok je 19 bolesnika bez delirija umrlo ( $\mathrm{p}=0,092)$. Logistička regresijska analiza odbacila je bilo kakvu povezanost delirija sa smrtnošću bolesnika ( $\mathrm{p}=0$,998). Dob, spol, anestezija, mehanička ventilacija i vrsta kirurškog zahvata nisu se mogli procijeniti kao čimbenici rizika za delirij. U slovenskim JIL zabilježen je manji udio delirija u usporedbi sa sličnim studijama. Čimbenici rizika kao što su spol, dob, mehanička ventilacija, sedacija, anestezija ili odjel ne mogu predvidjeti delirij. Međutim, dugotrajna hospitalizacija bolesnika u JIL mogla je predvidjeti početak delirija, ali prisutnost delirija nije povećala smrtnost bolesnika.

Ključne riječi: Delirij; Jedinice za intenzivno liječenje; Psibomotorna agitacija - klasifikacija; Svijest - klasifikacija; Kirurški odjel, bolnički; Slovenija 